\title{
ZMIENNOŚĆ ŁADUNKÓW ZANIECZYSZCZEŃ DOPEYWAJĄCYCH DO OCZYSZCZALNI ŚCIEKÓW W STALOWEJ WOLI
}

\begin{abstract}
W pracy przedstawiono analizę zmienności ładunków zanieczyszczeń dopływających do Miejskiej Oczyszczalni Ścieków w Stalowej Woli. Oczyszczalnia funkcjonuje od 1993 roku, a w latach 2006 - 2009 została przeprowadzona jej gruntowna modernizacja. Proces technologiczny opiera się na dwustopniowym, mechaniczno-biologicznym oczyszczaniu ścieków, z przeróbką osadów i dodatkowo z podwyższonym stopniem usuwania substancji biogennych. Projektowana średniodobowa przepustowość maksymalna wynosi $17500 \mathrm{~m}^{3} / \mathrm{d}$, natomiast równoważna liczba mieszkańców to 100000 RLM. Przeprowadzona analiza zmienności ładunków zanieczyszczeń dopływających do oczyszczalni obejmuje okres od 1 stycznia 2009 roku do 30 września 2015 roku w odniesieniu do sześciu wybranych wskaźników zanieczyszczeń: $\mathrm{BZT}_{5}, \mathrm{ChZT}_{\mathrm{Cr}}$, zawiesiny ogólnej, azotu ogólnego, fosforu ogólnego, azotu amonowego, a także dodatkowo ładunków wybranych metali ciężkich. W badanym okresie obciążenie hydrauliczne oczyszczalni kształtowało się poziomie od $5230,0 \mathrm{~m}^{3} / \mathrm{d}$ do $16800,0 \mathrm{~m}^{3} / \mathrm{d}$, a jego średnia wartość wynosiła $7137,6 \mathrm{~m}^{3} / \mathrm{d}$ i stanowiła około $41 \%$ projektowanego maksymalnego przepływu. Stężenia wybranych wskaźników zanieczyszczeń, jak również ładunki zanieczyszczeń zawarte w ściekach surowych kształtowały się na zróżnicowanych poziomach, co wynika ze zmiennych przepływów ścieków dopływających do oczyszczalni i różnorodności źródeł pochodzenia ścieków. Duży wpływ na zmienną jakość i ilość ścieków dopływających do oczyszczalni w Stalowej Woli maja wody opadowe. Przeprowadzona analiza zmienności ładunków zanieczyszczeń dopływających do oczyszczalni stanowi pomocne narzędzie przy optymalizacji pracy obiektu oraz przy planowaniu ewentualnej modernizacji.
\end{abstract}

Słowa kluczowe: oczyszczalnia ścieków, ścieki surowe, ładunki zanieczyszczeń, metale ciężkie

\footnotetext{
${ }^{1}$ Anna Krupicz, Politechnika Rzeszowaska

2 Autor do korespondencji/corresponding author: Adam Masłoń, al. Powstańców Warszawy 12, 35-959 Rzeszów, tel. 1774324 07, amaslon@prz.edu.pl
} 


\section{Wprowadzenie}

Oczyszczalnie ścieków są obiektami, które muszą zagwarantować właściwe oczyszczanie ścieków dopływających do nich z obszarów wiejskich i miejskich w takim stopniu, aby spełniały wymagania stawiane w aktualnie obowiązujących przepisach prawnych. Efektywność procesu oczyszczania ścieków zależy od szeregu powiązanych ze sobą procesów fizycznych, biologicznych i chemicznych danego systemy technologicznego. Skuteczność i stabilność zachodzenia tych procesów jest uzależniona od wielu czynników mających wpływ na właściwe działanie każdej oczyszczalni ścieków. Jednym z głównych czynników mającym wpływ na proces oczyszczania ścieków jest zmienność ilościowojakościowa ścieków dopływających do oczyszczalni. Właściwe określenie ładunków zanieczyszczeń ścieków dopływających jest dużym problemem dla eksploatatorów oczyszczalni zarówno w zakresie jej projektowania jak i eksploatacji. W tym celu przeprowadza się szczegółowe analizy ścieków surowych, które pozwalają właściwie dobrać parametry i urządzenia, które przekładają się na prawidłową eksploatację całą technologię oczyszczania ścieków [1].

\section{Opis obiektu badań}

Miejska Oczyszczalnia Ścieków w Stalowej Woli znajduje się w północnowschodniej części miasta przy ulicy Działkowej 1. Obiekt zlokalizowany jest na terenach nadrzecznych lewego brzegu rzeki San, która jest odbiornikiem ścieków oczyszczonych. W Stalowej Woli (woj. podkarpackie) ścieki miejskie i deszczowe odprowadzane są systemem kanalizacji rozdzielczej. Miasto posiada 100 kilometrów sieci kanalizacyjnej, która odprowadza ścieki do Miejskiej Oczyszczalni Ścieków. Z terenów nieskanalizowanych ścieki są dowożone do oczyszczalni wozami asenizacyjnymi. Układ kanalizacji w przeważającej części pracuje grawitacyjnie, lokalne przepompownie ścieków są przystosowane do pracy automatycznej (bez konieczności stałej obsługi) [2].

Badany obiekt funkcjonuje od września 1993 roku. Początkowo praca oczyszczalni opierała się na oczyszczaniu ścieków mechanicznym i biologicznym, bez usuwania azotu i fosforu, które mogą być źródłem wtórnego zanieczyszczenia wód powierzchniowych. Technologia oczyszczania ścieków, a także obiekty oczyszczalni były przestarzałe w porównaniu do zmieniających się norm dotyczących oczyszczania ścieków, które aktualnie obowiązywały w Polsce i Unii Europejskiej. Dlatego też w latach 2006 - 2009 została przeprowadzona gruntowna modernizacja MOŚ w Stalowej Woli. Modernizacja procesu technologicznego opierała się na zachowaniu dwustopniowego oczyszczania ścieków mechaniczno-biologicznego, z przeróbką osadów w zamkniętych komorach fermentacyjnych i dodatkowo z podwyższonym stopniem usuwania substancji biogennych - azotu i fosforu, ze wspomaganiem w postaci stosowania soli żelaza (PIX) i metanolu. Równoważna liczba mieszkańców (RLM) projektowana była 
podczas modernizacji na około 100000 RLM. Przepustowość maksymalna oczyszczalni określona jest na poziomie $17500 \mathrm{~m}^{3} / \mathrm{d}$ [2].

Ciąg technologiczny oczyszczalni aktualnie obejmuje część mechaniczną (dwie kraty schodkowe gęste, czterokomorowy piaskownik poziomy, dwa osadniki poziome podłużne), biologiczną (komora beztlenowa, tlenowa i anoksyczna, komora predenitryfikacji, dwa osadniki radialne) i linię przeróbki osadów (dwa zagęszczacze grawitacyjne, dwie wydzielone komory fermentacji WKF, stacja odwadniania osadów ściekowych) [2].

\section{Metodyka badań}

Metodyka oceny zmienności ładunków zanieczyszczeń dopływających do oczyszczalni ścieków oparta jest na wynikach badań jakościowych oraz przepływach dobowych ścieków surowych, w okresie od 1 stycznia 2009 roku do 30 września 2015 roku, udostępnionych przez eksploatatora Miejskiego Zakładu Komunalnego Sp. z. o.o. w Stalowej Woli. Liczba wyników n= 168. W pracy dokonano analizy zmienności obciążenia hydraulicznego na podstawie rozkładu dobowej ilości ścieków dopływających do oczyszczalni $\left(Q_{\text {śrd }}\right)$, jakości ścieków surowych, ładunków zanieczyszczeń wybranych wskaźników zanieczyszczeń $\left(\mathrm{BZT}_{5}, \mathrm{ChZT}_{\mathrm{Cr}}\right.$, zawiesiny ogólnej, azotu ogólnego, fosforu ogólnego, azotu amonowego), a także równoważnej liczby mieszkańców (RLM). Określono zmienność ładunków metali ciężkich (cynku, miedzi, niklu, chromu ogólnego oraz chromu (VI)) zawartych w ściekach dopływających do oczyszczalni. Określono podstawowe charakterystyki statystyczne (średnią, minimum, maksimum, medianę, odchylenie standardowe, rozstęp, percentyl 15\% i 85\%).

\section{Wyniki i dyskusja}

W okresie od 1 stycznia 2009 roku do 30 września 2015 roku obciążenie hydrauliczne obiektu kształtowało się na bardzo zróżnicowanym poziomie: od $5230,0 \mathrm{~m}^{3} / \mathrm{d}$ do $16800,0 \mathrm{~m}^{3} / \mathrm{d}$ (Tab. 1). Średnia wartość obciążenia hydraulicznego z rozpatrywanego okresu wynosiła $7137,6 \mathrm{~m}^{3} / \mathrm{d}$, stanowiąc około $41 \%$ projektowanego maksymalnego przepływu, co pozwala stwierdzić, że oczyszczalnia jest niedociążona hydraulicznie, ale dzięki temu zwiększa to jej rezerwy przepustowości na wypadek wystąpienia nagłych i dużych dopływów ścieków spowodowanych na przykład obfitymi opadami atmosferycznymi.

Zróżnicowanie przepływów średniodobowych w latach 2009-2011 utrzymywało się między wartościami od $7000 \mathrm{~m}^{3} / \mathrm{d}$ do $8500 \mathrm{~m}^{3} / \mathrm{d}$, natomiast w latach 2012-2015 zaobserwowano zmniejszenie ilości ścieków dopływających do poziomu od $6000 \mathrm{~m}^{3} / \mathrm{d}$ do $7500 \mathrm{~m}^{3} / \mathrm{d}$. Sporadycznie pojawiały się wysokie przepływy ścieków, zazwyczaj występujące w okresach letnich (tj. od czerwca do sierpnia) spowodowane intensywnymi opadami deszczu i w okresach przejściowych między zimą a wiosną, gdzie wzrost ilości ścieków powodowało topnienie 
pokrywy śnieżnej. W roku 2010 odnotowano znaczny wzrost ilości ścieków na co miały wpływ występujące w tym okresie intensywne opady atmosferyczne, to właśnie w tym roku zaobserwowano największą wartość przepływu w całym analizowanym siedmioleciu, który pojawił się w lipcu i wynosił $16800 \mathrm{~m}^{3} / \mathrm{d}$, czyli znacznie zbliżył się do przepływu projektowego. Analizując cały okres badań można łatwo stwierdzić, że ilość ścieków dopływających do oczyszczalni jest ściśle związana z występowaniem opadów atmosferycznych, które powodują znaczne zwiększenie się objętości ścieków trafiających do oczyszczalni w okresach, w których się pojawiają.

W rozpatrywanym okresie zaobserwowano znaczne obniżenie ilości ścieków dopływających do oczyszczalni (Rys. 1). Tendencję spadkową widać także w innych miejskich oczyszczalniach na terenie Polski [3]. Sytuacja ta jest spowodowana prawdopodobnie znacznym obniżeniem ilości opadów atmosferycznych (których znaczna część trafia do kanalizacji, a następnie od oczyszczalni) zarówno w miesiącach letnich jak i zimowych, a także zmniejszeniem zużycia wody spowodowanym wysokimi kosztami i wzrostem świadomości ekologicznej ludzi, którzy coraz większą wagę przywiązują do ochrony otaczającego nas środowiska.

Tabela 1. Charakterystyka ilościowa ścieków dopływających do oczyszczalni w Stalowej Woli

Table 1. Quantitative characteristics of wastewater flowing to the Stalowa Wola WWTP

\begin{tabular}{|c|c|c|c|c|c|c|c|c|}
\hline \multirow{2}{*}{$\begin{array}{c}\text { Statystyka } \\
\text { opisowa }\end{array}$} & \multicolumn{8}{|c|}{ Przepływ $\left[\mathrm{m}^{3} / \mathrm{d}\right]$} \\
\hline & 2009 & 2010 & 2011 & 2012 & 2013 & 2014 & $2015 *$ & $\begin{array}{l}\text { 2009- } \\
\text { 2015* }\end{array}$ \\
\hline Średnia & 7693,8 & 7941,0 & 7543,8 & 6874,9 & 6917,4 & 6823,1 & 6169,1 & 7137,6 \\
\hline Minimum & 6000,0 & 6460,0 & 6000,0 & 5620,0 & 5640,0 & 5580,0 & 5230,0 & 5230,0 \\
\hline Maksimum & 112600 & 16800 & 12400 & 12530 & 13800 & 10390 & 8900 & 16800 \\
\hline Mediana & 7560,0 & 7730,0 & 7390,0 & 6740,0 & 6740,0 & 6700,0 & 6100,0 & 6740,0 \\
\hline Odch. stand. & 735,7 & 1050,8 & 839,9 & 687,7 & 804,9 & 671,8 & 514,2 & 166,8 \\
\hline Rozstęp & 5260,0 & 10340,0 & 6400,0 & 6910,0 & 8160,0 & 4810,0 & 3670,0 & $\begin{array}{c}11570, \\
0\end{array}$ \\
\hline Percentyl 15\% & 7080,0 & 7080,0 & 6822,0 & 6380,0 & 6290,0 & 6256,0 & 5730,0 & 6314,5 \\
\hline Percentyl 85\% & 8312,0 & 8748,0 & 8246,0 & 7305,0 & 7420,0 & 7354,0 & 6530,0 & 8000,0 \\
\hline
\end{tabular}

* obejmuje okres od 1 stycznia do 30 września 


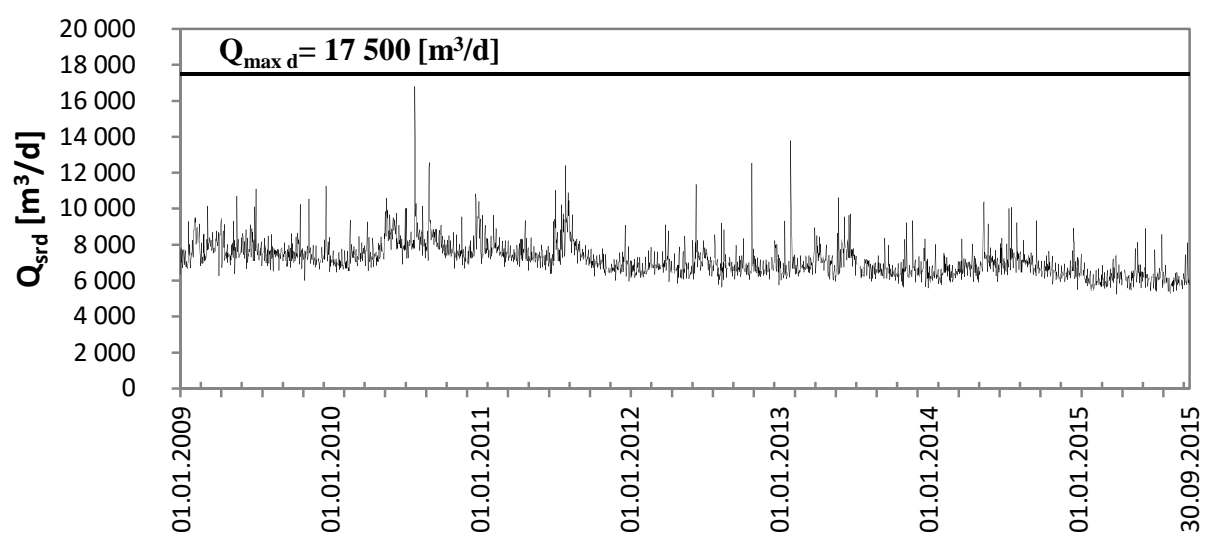

Rys. 1. Średnie dobowe ilości ścieków dopływające do oczyszczalni w Stalowej Woli w okresie od 1.01.2009 do 30.09.2015 r.

Fig. 1. The average daily volume of wastewater flowing into the Stalowa Wola WWTP in the period from 1.01.2009 to 30.09.2015

Wartości zanieczyszczeń w ściekach surowych były dość zróżnicowane w całym okresie badawczym (Rys. 2). Znaczny wpływ na charakterystykę parametrów jakościowych miała zmienność przepływów ścieków dopływających do oczyszczalni, a także różnorodność źródeł, z których te ścieki pochodzą (ścieki bytowe, $\mathrm{z}$ zakładów przemysłowych, ścieki deszczowe i roztopowe). Ważnym czynnikiem warunkującym skład ścieków surowych jest pogoda. W czasie pogody bezdeszczowej stężenia dopływających zanieczyszczeń były znacznie wyższe niż w czasie pogody deszczowej, gdzie następuje rozcieńczenie ścieków wodami opadowymi.

Stężenia związków organicznych wyrażonych za pomocą $\mathrm{BZT}_{5}$ kształtowały się w przedziale od 275,0 (lipiec 2009 r.) do $654,0 \mathrm{mg} \mathrm{O}_{2} / \mathrm{dm}^{3}$ (marzec $2015 \mathrm{r}$.).

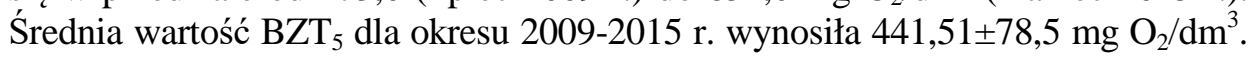
Obserwowany jest niejednostajny wzrost stężeń zw. organicznych, mimo okresowych spadków (Rys. 2). Z kolei zawartość substancji organicznych wyrażonych wskaźnikiem ChZT $\mathrm{Cr}_{\mathrm{r}}$ oscylowała w przedziale $428,0-1809,0 \mathrm{mg} \mathrm{\textrm {O } _ { 2 }} / \mathrm{dm}^{3}$, przy średniej wartości $1087,59 \pm 207,7 \mathrm{mg} \mathrm{O}_{2} / \mathrm{dm}^{3}$. W okresie 2009-2011 roku znaczny spadek wartości ChZT $\mathrm{Cr}_{\mathrm{Cr}}$ oznaczanego w ściekach, w porównaniu z pozostałymi latami. Na przełomie 2012 i 2013 roku miał miejsce wzrost ilości związków organicznych wyrażonych wskaźnikiem $\mathrm{ChZT}_{\mathrm{Cr}}$. Stężenia zawiesiny ogólnej w analizowanym siedmioleciu rozkładały się równomierne i kształtowały się na poziomie około $498,79 \pm 135,91 \mathrm{mg} / \mathrm{dm}^{3}$. Na początku 2009 roku stężenie zawiesiny było znacząco niższe, później jednak systematycznie rosło, a od 2010 roku utrzymuje się na zbliżonym poziomie, mimo sporadycznych wzrostów i spadków. Zakres stężeń $Z_{\text {og }}$ wyniósł 234,0-1328,0 mg/dm³ . 

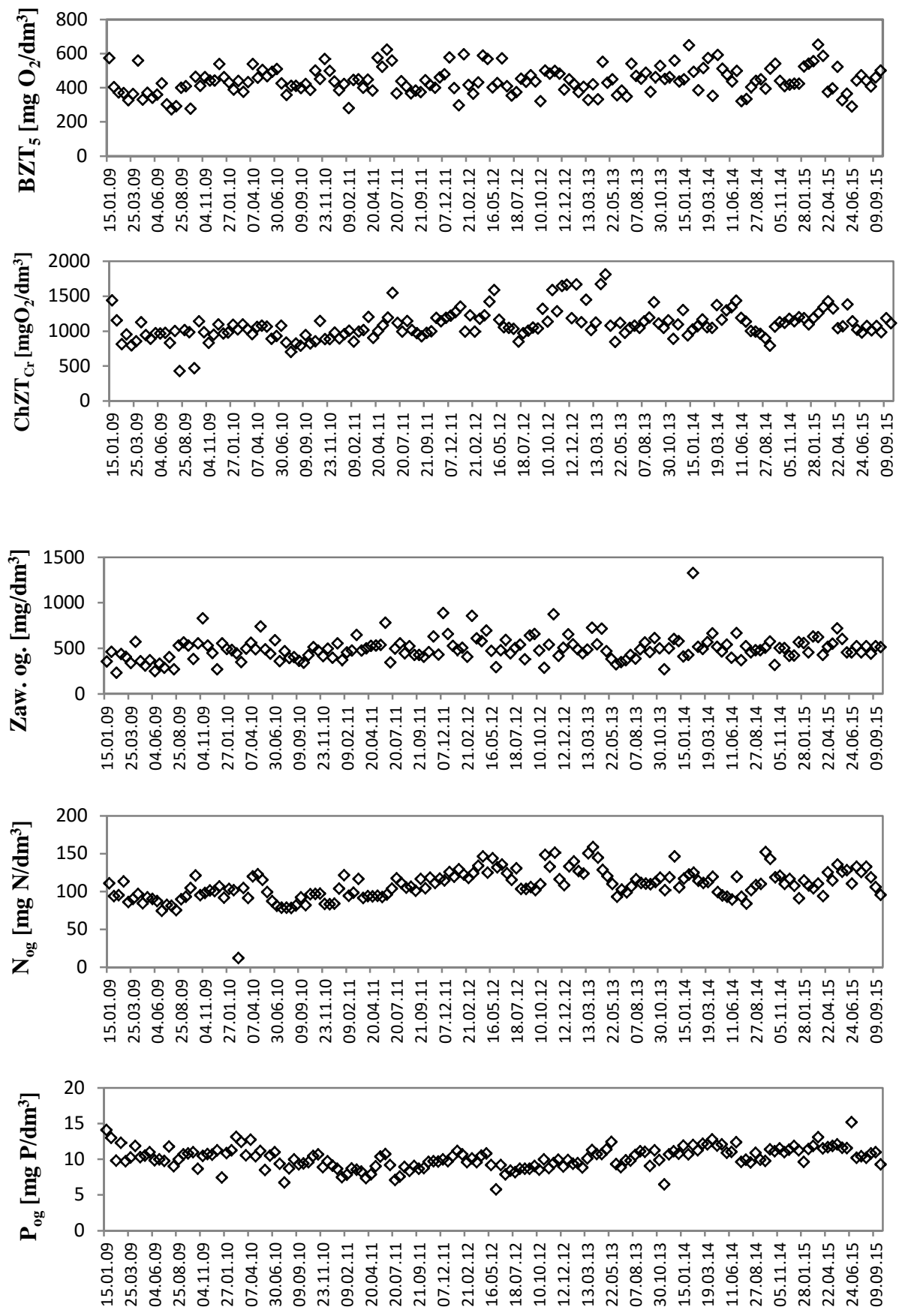

Rys. 2. Jakość ścieków dopływających do oczyszczalni w latach 2009-2015

Fig. 2. Quality of wastewater flowing into WWTP in years 2009-2015 
Stężenia azotu i fosforu ogólnego w ściekach surowych były również bardzo zróżnicowane. Stężenie związków biogennych w analizowanym wieloleciu oscylowało w zakresach $11,87-158,93 \mathrm{mg} \mathrm{N} / \mathrm{dm}^{3}$ oraz $5,80-15,20 \mathrm{mg} \mathrm{P} / \mathrm{dm}^{3}$, przy średnich wartościach na poziomie $108,62 \pm 19,4 \mathrm{mg} \mathrm{N} / \mathrm{dm}^{3}$ i $10,19 \pm 1,47 \mathrm{mg} \mathrm{P} / \mathrm{dm}^{3}$. W przypadku azotu ogólnego znaczny wzrost stężenia nastąpił od 2011 roku i kształtował się na poziomie od 100 do $130 \mathrm{mg} \mathrm{N} / \mathrm{dm}^{3}$. Natomiast najniższe stężenia fosforu ogólnego w badanym okresie dopływały do oczyszczalni w latach 2009-2012. Od 2012 roku do końca analizowanego okresu nastąił wzrost zawartości fosforu w ściekach surowych. W przypadku analizy azotu amonowego w ściekach surowych widoczne jest znaczne podobieństwo do rozkładu stężeń azotu ogólnego. Wysokim wartościom azotu ogólnego odpowiadały wysokie stężenia azotu amonowego. Najniższe stężenie azotu amonowego w dopływie do oczyszczalni odnotowano w lipcu $2010 \mathrm{r}$. $\left(51,4 \mathrm{mg} \mathrm{N} / \mathrm{dm}^{3}\right)$, z kolei najwyższe stężenie w marcu 2013 r. $\left(122,14 \mathrm{mg} \mathrm{N} / \mathrm{dm}^{3}\right.$. Wartość średnia $\mathrm{N}-\mathrm{NH}_{4} \mathrm{w}$ analizowanym siedmioleciu wynosi $82,76 \pm 15,87 \mathrm{mg} \mathrm{N} / \mathrm{dm}^{3}$.

W przypadku analizowanych wskaźników można zaobserwować pewną prawidłowość skorelowaną z nierównomiernością dopływających ścieków do oczyszczalni (Rys. 1). Podobne zależności obserwowane są niemal we wszystkich oczyszczalniach ścieków miejskich o zbliżonej przepustowości $[3,4,5]$. W latach 2009-2012, w których ilości ścieków surowych dopływających do oczyszczalni były znacznie wyższe, obserwowano obniżone wartości wskaźników poszczególnych zanieczyszczeń, co było prawdopodobnie spowodowane rozcieńczaniem stężeń zanieczyszczeń głównie wodami deszczowymi trafiającymi do kanalizacji. Natomiast w ostatnich latach, gdy obniżeniu uległa ilość ścieków kierowanych do oczyszczalni, odnotowano wzrost ilości związków organicznych, zawiesiny ogólnej oraz związków biogennych w ściekach surowych.

Metale ciężkie stanowią specyficzne zanieczyszczenia w ściekach komunalnych. Źródłem metali ciężkich dostających się do kanalizacji są głównie zakłady przemysłowe oraz spływy powierzchniowe. W rozpatrywanym okresie zaobserwowano niewielkie zróżnicowanie stężeń wybranych metali ciężkich w ściekach surowych (Rys. 3).

Najmniejszym rozstępem charakteryzował się chrom (VI). W przypadku pozostałych metali ciężkich ich ilość uzależniona jest od obciążenia hydraulicznego oczyszczalni. W pierwszej fazie spływu wód deszczowych obserwuje się znaczne ilości metali ciężkich. W okresie bezdeszczowym obserwuje się z kolei mniejsza zawartość metali ciężkich w ściekach surowych. Zawartość metali ciężkich w ściekach dopływających do stalowowolskiej oczyszczalni jest typowa dla ścieków miejskich. Graniczne wartości stężeń cynku oscylowały w przedziale 0,11-0,66 mg Zn/ $\mathrm{dm}^{3}$, a wartość średnia dla analizowanego okresu wyniosła $0,24 \pm 0,06 \mathrm{mg} \mathrm{Zn} / \mathrm{dm}^{3}$. Stężenia miedzi oscylowały między 0,01 i $0,12 \mathrm{mg} \mathrm{Cu} / \mathrm{dm}^{3}$, przy czym średnia wartość osiągnęła poziom $0,04 \pm 0,01 \mathrm{mg} \mathrm{Cu} / \mathrm{dm}^{3}$. Stężenie niklu kształtowało się na poziomie $0,07 \pm 0,03 \mathrm{mg} \mathrm{Ni} / \mathrm{dm}^{3}$. W analizowanym 
siedmioleciu obserwowane jest stopniowe obniżanie się ilości niklu w ściekach surowych. Stężenie niklu w ściekach surowych kształtowało się na poziomie od 0,03 do $0,18 \mathrm{mg} \mathrm{Ni} / \mathrm{dm}^{3}$. Stężenia chromu ogólnego i chromu (VI) kształtowały się na bardzo niskim poziomie, często na granicy oznaczalności $0,01 \mathrm{mg} \mathrm{Cr} / \mathrm{dm}^{3}$. Wartości średnie z okresu 2009-2015 roku wyniosły $0,013 \pm 0,006 \mathrm{mg} \mathrm{Cr} / \mathrm{dm}^{3}$ i 0,010 $\pm 0,001 \mathrm{mg} \mathrm{Cr}{ }^{6+} / \mathrm{dm}^{3}$ odpowiednio dla chromu ogólnego i chromu (VI). Większość pomiarów w obu przypadkach wynosiła $0,01 \mathrm{mg} \mathrm{Cr}^{6+} / \mathrm{dm}^{3}$, zwłaszcza w przypadku chromu (VI). Stężenia chromu ogólnego zawierały się w przedziale od 0,009 do $0,040 \mathrm{mg} \mathrm{Cr} / \mathrm{dm}^{3}$, natomiast chromu (VI) od 0,001 do 0,020 mg $\mathrm{Cr}^{6+} / \mathrm{dm}^{3}$.

Zróżnicowanie ilości i jakości ścieków dopływających do oczyszczalni wpływa na zmienny rozkład ładunków zanieczyszczeń. W okresie od 1 stycznia 2009 do 30 września 2015 roku nie odnotowano sezonowości w dopływie zanieczyszczeń do oczyszczalni zarówno $\mathrm{w}$ ujęciu rocznym, jak i miesięcznym (Rys. 4). Wartość średnia ładunku $\mathrm{BZT}_{5} \mathrm{w}$ ściekach surowych $\mathrm{w}$ analizowanym siedmioleciu wynosiła $3114,85 \pm 611,03 \mathrm{~kg} \mathrm{O}_{2} / \mathrm{d}$. W latach $2009-2011 \mathrm{i}$ w roku 2014 ładunki dobowe $\mathrm{BZT}_{5} \mathrm{w}$ dopływie do oczyszczalni były do siebie zbliżone i kształtowały się na poziomie powyżej $3000 \mathrm{~kg} \mathrm{O}_{2} / \mathrm{d}$. Z kolei w latach 2012, 2013 i 2015 nastąpiło nieznaczne obniżenie tej wartości odpowiednio do $2901,45 \mathrm{~kg} \mathrm{O}_{2} / \mathrm{d}, 2933,96 \mathrm{~kg} \mathrm{O}_{2} / \mathrm{d}$ i 2720,19 $\mathrm{kg} \mathrm{O}_{2} / \mathrm{d}$. Wielkość ładunku $\mathrm{BZT}_{5}$ w całym badanym okresie (mimo okresowych spadków i wzrostów w poszczególnych latach) ulegała systematycznemu obniżaniu. Rozkład ładunków zanieczyszczeń organicznych wyrażony wskaźnikiem ChZT $\mathrm{T}_{\mathrm{Cr}}$ kształtował się na poziomie od 3423,7 do $13115,25 \mathrm{~kg} \mathrm{O}_{2} / \mathrm{d}$, przy średniej $7615,77 \pm 1294,56 \mathrm{~kg} / \mathrm{d}$. W latach 2009-2010 obserwowano spadek ładunków ChZT $\mathrm{Cr}_{\mathrm{r}}$ w ściekach dopływających, natomiast na przełomie 2010 i 2011 roku nastąpił wzrost ładunków, który aż do 2014 roku utrzymywał się na bardzo zbliżonym poziomie- około $7800-8100 \mathrm{~kg} \mathrm{O}_{2} / \mathrm{d}$. Na początku 2014 roku ładunki $\mathrm{ChZT}_{\mathrm{Cr}}$ uległy obniżeniu, a ich spadek obserwowano do końca analizowanego okresu do wartości poniżej $6000 \mathrm{~kg} / \mathrm{d}$. Dobowe ładunki zawiesiny ogólnej wahały się od 1861,8 kg/d do $8552,32 \mathrm{~kg} / \mathrm{d}$. Od początku 2009 roku obserwowany był wzrost ładunku zawiesiny w ściekach, natomiast od końca roku 2010 widoczne jest jego systematyczne obniżanie aż do końca okresu prowadzenia obserwacji, pomimo sporadycznych wartości znacznie odbiegających od wartości średniej. Średni dobowy ła-

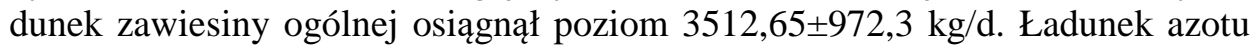
ogólnego oscylował w granicach wartości minimalnej równej 77,51 kg N/d i wartości maksymalnej wynoszącej 1319,98 kg N/d. Wartość średnia z okresu

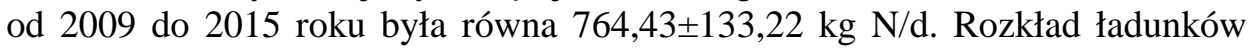
fosforu ogólnego $\mathrm{w}$ analizowanym siedmioleciu kształtował się na poziomie od 49,91 do 113,06 kg P/d, przy średnie wartości równej 72,32ะ10,46 kg P/d. 

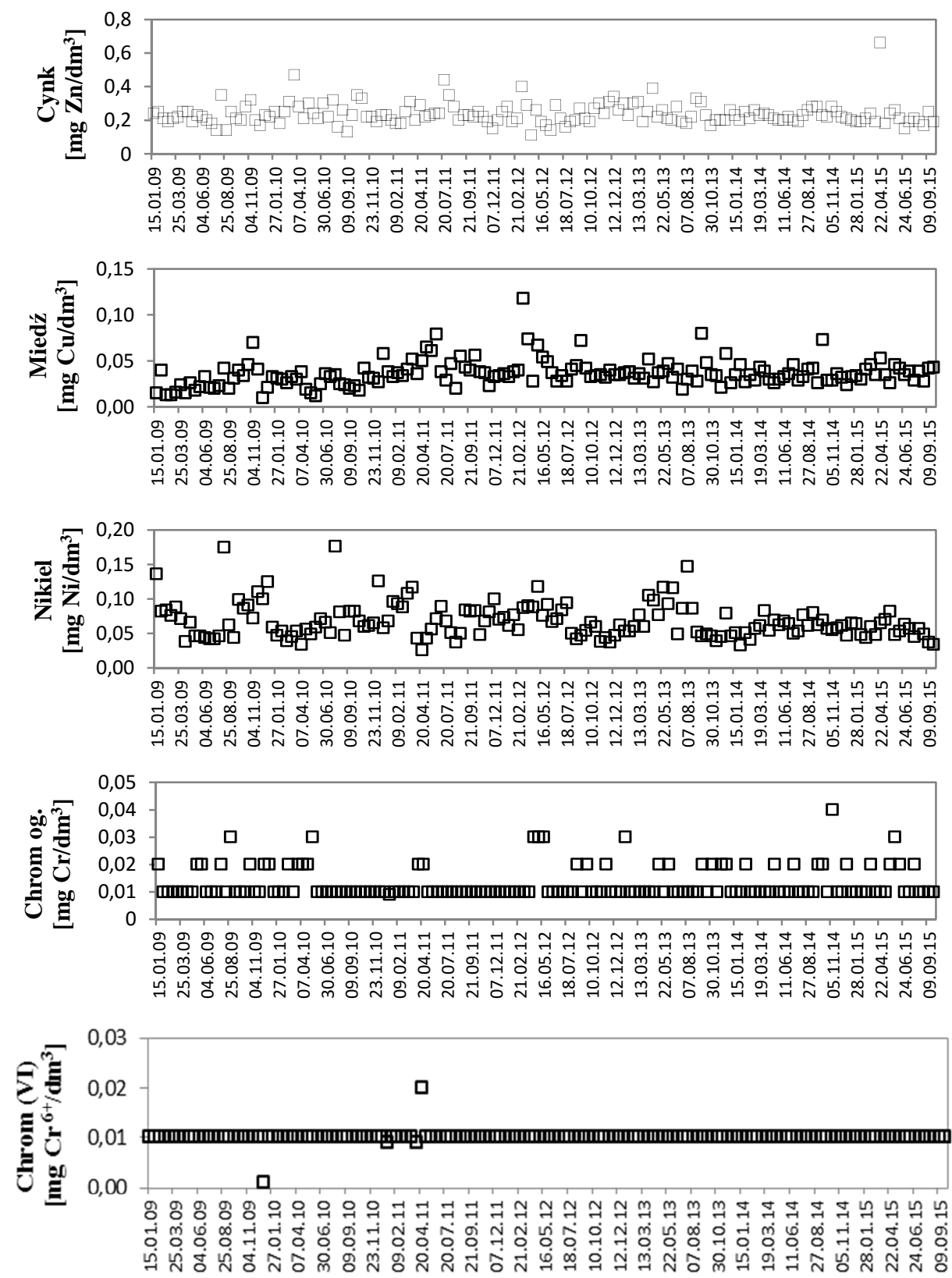

Rys. 3. Zawartość metali ciężkich w ściekach dopływających do oczyszczalni w latach 2009-2015

Fig. 3. The heavy metals concentration in wastewater flowing into WWTP in years 2009-2015 

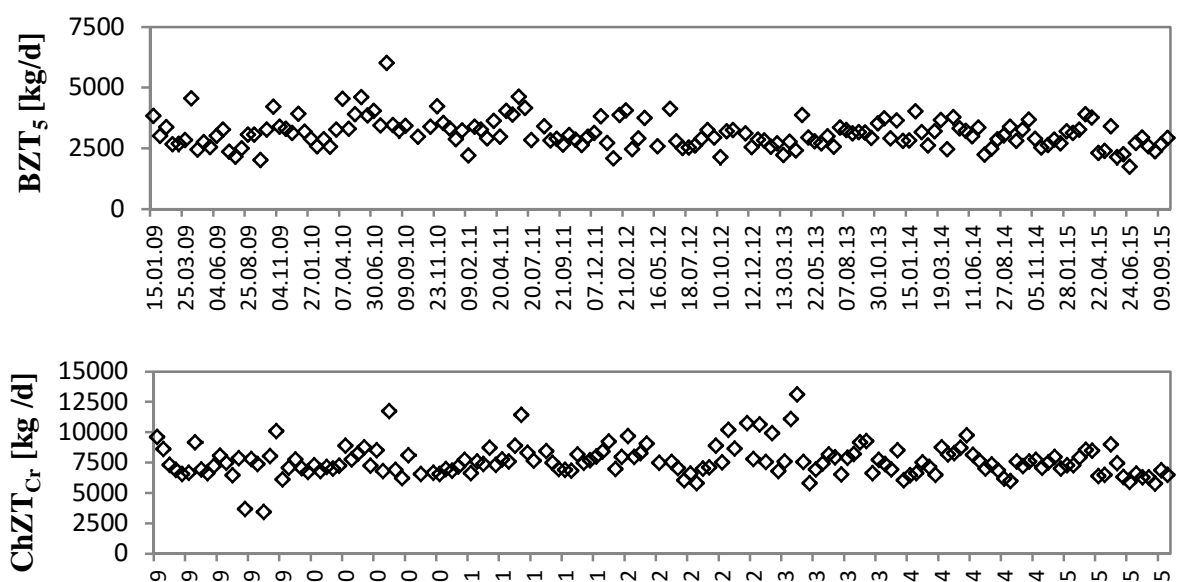

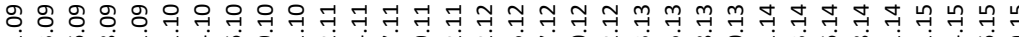

ठ

ம่
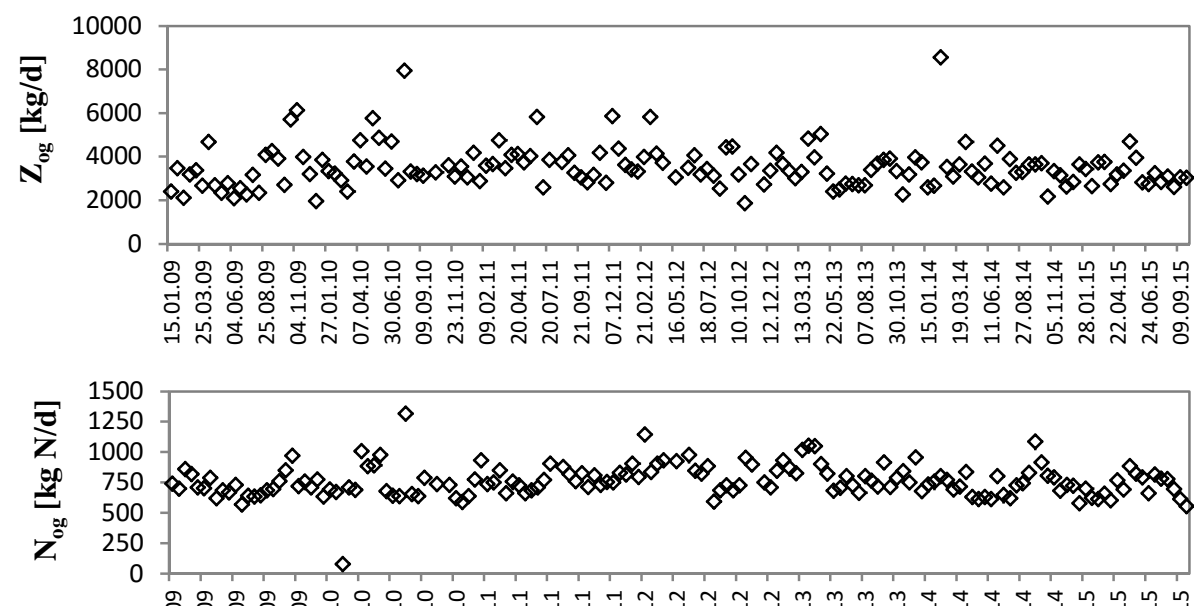

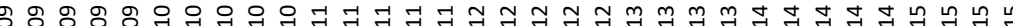

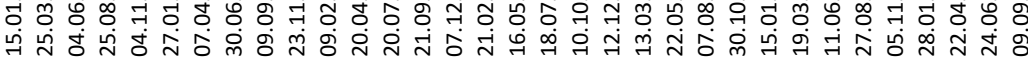

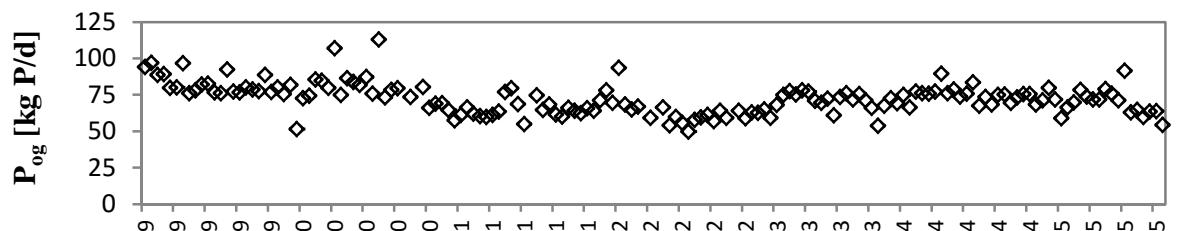

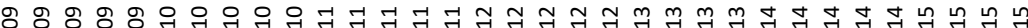

ठં

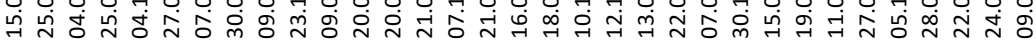

Rys. 4. Ładunki zanieczyszczeń w ściekach dopływających do oczyszczalni w latach 2009-2015

Fig. 4. The daily pollutant loads in wastewater flowing into WWTP in years 2009-2015 
Ilość metali ciężkich dopływających w ściekach do oczyszczalni w zasadniczym stopniu przekłada się na jakość osadu ściekowego powstającego jako produkt uboczny w oczyszczalni ścieków. Metale ciężkie w ściekach występują $\mathrm{w}$ formie zawiesin oraz $\mathrm{w}$ postaci rozpuszczonej. W procesach oczyszczania ścieków, w tym przede wszystkim chemicznego strącania fosforu ze ścieków za pomocą soli glinu lub żelaza, następuje ich znaczne usunięcia ze ścieków oraz migracja i kumulacja w osadach ściekowych. Ponadto procesy bioakumulacji metali ciężkich przez mikroorganizmy osadu czynnego oraz proces fermentacji metanowej (utworzenie niemobilnych siarczków metali ciężkich) sprzyjają transferowi metali ciężkich ze ścieków do osadów ściekowych [6, 7]. Zawartość metali ciężkich $\mathrm{w}$ ustabilizowanych osadach ściekowych determinuje $\mathrm{z}$ kolei kierunek ich zagospodarowania, w tym przyrodniczego wykorzystania [7]. Znaczne ilości metali ciężkich w ściekach surowych mogą prowadzić do negatywnych skutków technologii oczyszczania ścieków. Przykładowo problematycznym źródłem metali ciężkich w dopływie do miejskiej oczyszczalni mogą być ścieki z myjni pojazdów. W takich przypadkach konieczna jest kontrola jakości ścieków wprowadzanych do systemu kanalizacyjnego [8]. Na rysunku 5 przedstawiono dobowy rozkład ładunków metali ciężkich w latach 2009-2015. Zakres ładunków cynku w dopływie do oczyszczalni oscylował w przedziale od 0,702 (2012 r.) do 5,376 kg Zn/d (2010 r.). Wartość średnia wieloletnia kształtowała się na poziomie $1,688 \pm 0,577 \mathrm{~kg} \mathrm{Zn} / \mathrm{d}$. W analizowanym okresie zaobserwowano zmniejszenie ilości ładunków cynku zawartego w ściekach surowych dopływających do oczyszczalni z ok. 2,046 kg Zn/d w 2010 r. do 1,40 kg $\mathrm{Zn/d} \mathrm{w} 2015$ r. (wartości średnie roczne). Średnie dobowe ładunki innego metalu ciężkiego - miedzi kształtowały się na poziomie $0,255 \pm 0,108 \mathrm{~kg} \mathrm{Cu} / \mathrm{d}$. Wartość minimalna wyniosła $0,071 \mathrm{~kg} \mathrm{Cu} / \mathrm{d}$, maksymalna natomiast $0,798 \mathrm{~kg} \mathrm{Cu} / \mathrm{d}$. Do przełomu lat 2011 i 2012 odnotowano wzrost ilości ładunków miedzi, później jednak nastąpiło jego stopniowe obniżanie. Zakres dobowych ładunków niklu oscylował w przedziale $0,199-2,957 \mathrm{~kg} \mathrm{Ni} / \mathrm{d}$. Z kolei wartość średnia dla analizowanego wielolecia kształtowała się na poziomie $0,489 \pm 0,274 \mathrm{~kg} \mathrm{Ni} / \mathrm{d}$. Wartości ładunków niklu w ściekach dopływających były znacznie zbliżone, a znaczne odstępstwa od wartości średniej pojawiły się sporadycznie. W analizowanym okresie obserwowany jest stopniowy spadek zawartości ładunków niklu w ściekach surowych. Ładunki chromu ogólnego oscylowały w przedziale od $0,058 \mathrm{~kg}$ $\mathrm{Cr} / \mathrm{d}$ do $0,263 \mathrm{~kg} \mathrm{Cr} / \mathrm{d}$, przy średniej na poziomie $0,092 \pm 0,041 \mathrm{~kg} \mathrm{Cr} / \mathrm{d}$. Na początku analizowanego okresu (2009/2010) nastąpił znaczny wzrost ilości ładunków chromu ogólnego, a następnie powolny jego spadek. W latach 2011-2013 poziom ładunków chromu ogólnego w dopływających do oczyszczalni ścieków utrzymywał się na bardzo zbliżonym poziomie. Pod koniec 2013 zaobserwowano ponownie niewielki wzrost ładunku chromu, jednak w 2015 roku ilość ładunków $\mathrm{Cr}_{\mathrm{og}}$ gwałtownie spadła. Z kolei dobowy rozkład ładunków chromu (VI) oscylował w przedziale $0,007 \mathrm{~kg} \mathrm{Cr}^{6+} / \mathrm{d}$ do $0,168 \mathrm{~kg} \mathrm{Cr}^{6+} / \mathrm{d}$. Wartość średnia kształtowała się na poziomie $0,071 \pm 0,014 \mathrm{~kg} \mathrm{Cr}^{6+} / \mathrm{d}$. Rozkład ładunków chromu (VI) był bardzo zbliżony do rozkładu ładunków chromu ogólnego. 

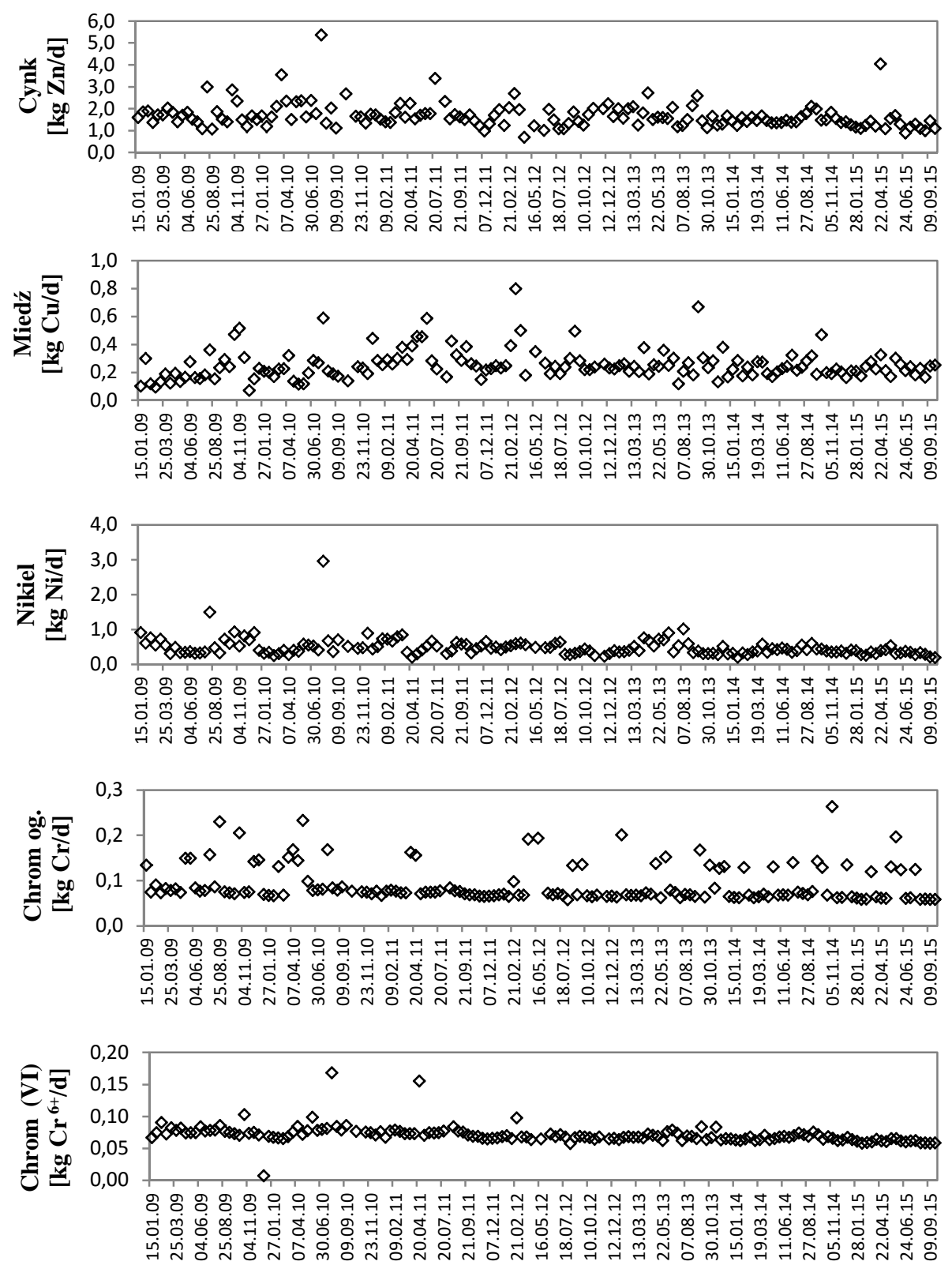

Rys. 5. Ładunki metali ciężkich w ściekach dopływających do oczyszczalni w latach 2009-2015

Fig. 5. The heavy metals loads in wastewater flowing into WWTP in years 2009-2015 
Zmienne ilości dopływających ścieków, a także zmienne wartości parametrów zanieczyszczeń mają bezpośredni wpływ na wielkość ładunków zanieczyszczeń w ściekach surowych. W przypadku wszystkich analizowanych parametrów zaobserwowano spadki ilości ładunków zanieczyszczeń na końcu analizowanego okresu, w porównaniu z jego początkiem. Mimo przejściowych okresów wzrostów i tak wartości ulegały systematycznemu obniżaniu. W przypadku ładunku zanieczyszczeń, również można powiązać przebieg ich wartości w okresie 2009-2015 roku z rozkładem przepływów w tymże okresie, które także ulegały obniżeniu oraz z rozkładem stężeń analizowanych wskaźników, który z kolei zazwyczaj miał tendencję wzrostową w ostatnich latach badanego siedmiolecia.

W odniesieniu do RLM obiektu obserwowane jest utrzymywanie się wartości średnich powyżej $50000 \mathrm{w}$ przeważającej części analizowanego okresu, jedynie w latach 2012 i 2015 następuje spadek poniżej 50000. Wartość średnia z całego siedmiolecia była równa 51914, czyli około 52\% wartości projektowanej, która wynosi 100000.

\section{Podsumowanie}

W analizowanym okresie, od 1 stycznia 2009 r. do 30 września 2015 r. do miejskiej oczyszczalni w Stalowej Woli dopływały ścieki w średniej ilości $7137,6 \mathrm{~m}^{3} / \mathrm{d}$, co stanowiło około $41 \%$ projektowanego maksymalnego przepływu obiektu. Aktualnie oczyszczalnia ścieków jest niedociążona hydraulicznie i posiada znaczne rezerwy przepustowości. Ilość ścieków dopływających do oczyszczalni w analizowanym okresie uległa znacznemu spadkowi w końcowym okresie w latach 2014-2015, na co wpływ ma wiele czynników m. in. obserwowane obniżenie ilości opadów atmosferycznych, a także zmniejszenie zużycia wody spowodowane wysokimi kosztami oraz wzrostem troski ludzi o środowisko.

W ostatnich latach nastąpił wzrost ilości związków organicznych, zawiesiny ogólnej i związków biogennych, a także niektórych metali ciężkich w ściekach surowych. Wpływ na to zjawisko ma prawdopodobnie zmniejszająca się ilość ścieków dopływających do obiektu, która warunkuje zatężenie zawartych zanieczyszczeń i zaobserwowany wzrost ich stężeń.

Przeprowadzona analiza zmienności ładunków zanieczyszczeń dopływających do oczyszczalni stanowi pomocne narzędzie przy optymalizacji pracy obiektu oraz przy planowaniu ewentualnej modernizacji.

\section{Literatura}

[1] Dymaczewski Z.: Poradnik eksploatatora oczyszczalni ścieków. PZITS. 2011.

[2] Miejski Zakład Komunalny Sp. z. o.o. w Stalowej Woli. Materiały informacyjne.

[3] Maj K., Masłoń A.: Wieloparametryczna ocena efektywności oczyszczalni ścieków w Rzeszowie przed modernizacją. Czasopismo Inżynierii Lądowej, Środowiska i Architektury, nr 62, 2015, s. 299-315. 
[4] Kołacz K., Piaskowski K.: Zmienność ilościowo-jakościowa ścieków surowych w oczyszczalni ścieków komunalnych, Forum Eksploatatora, nr 54, 2011, s. 62-69.

[5] Tomczuk B.: Zmienność ilości ścieków i nieczystości ciekłych oraz ładunku zanieczyszczeń na przykładzie oczyszczalni ścieków komunalnych w Lipsku nad Biebrzą, Inżynieria Ekologiczna, nr 24, 2011, s. 145-153.

[6] Gawdzik J., Latosińska J.: Analiza mobilności metali ciężkich w wybranych osadach ściekowych z oczyszczalni o różnej przepustowości. Proceedings of ECOpole, 2012, 6(1), s. 319-324.

[7] Gworek B., Wilk M.: Metale ciężkie w osadach ściekowych. Ochrona Środowiska i Zasobów Naturalnych, nr 39, 2009, s. 40-59.

[8] Kuzemko J.: Odprowadzanie ścieków zawierających substancje niebezpieczne do kanalizacji miejskiej (na przykładzie kontroli myjni pojazdów) - wymagania prawne i techniczne ewentualne skutki negatywne dla technologii oczyszczalni zbiorowej. XVIII Kongres Naukowo-Techniczny WOD-KAN-EKO 2015. Serock k. Warszawy, 17-18 listopada 2015 r. Materiały konferencyjne s. 53-57.

\section{VARIABILITY LOADS OF POLLUTANTS FLOWING INTO THE WASTEWATER TREATMENT PLANT IN STALOWA WOLA}

\section{S u m m a r y}

The paper presents an analysis of the variability of pollution loads flowing into the Stalowa Wola WWTP. Treatment plant operates since 1993, in the years 2006-2009 was carried out its profound modernization. Technological process is based on a two-step process, biological wastewater treatment, mechanical reworking of sediments and in addition with an elevated degree of removal of biogenic substances. The proposed maximum bandwidth the average daily is $17500 \mathrm{~m} 3 / \mathrm{d}$, while the population equivalent P.E. 100,000. Carried out the analysis covers the period from 1 January 2009 to 30 September 2015, and its objective is to determine the variability of pollutants to-floating to the treatment plant for the six selected indicators solution-cleanings: $\mathrm{BOD}_{5}, \mathrm{COD}$, total suspended solids, total nitrogen, total phosphorus, ammonia nitrogen and additional loads of heavy metals. During the period the load hydraulic treatment stood at posing new very-diverse: from $5230,0 \mathrm{~m}^{3} / \mathrm{d}$ to $16800,0 \mathrm{~m}^{3} / \mathrm{d}$ and its average value is $7137,6 \mathrm{~m}^{3} / \mathrm{d}$ and accounts for about $41 \%$ of projected maximum flow. Concentrations of selected indicators of pollution, as well as loads of pollutants contained in raw sewage are on different levels, as a result of the variables of the influent flow to the treatment plant and the diversity of sources of origin. A large impact on the quality and quantity of the variable influent to the Stalowa Wola WWTP may runoff water. Waste water treatment of the incoming raw analysis carried out can be helpful when planning the possible upgrading or improving the efficiency of processes, so as to reasonably exploit the entire wastewater treatment technology.

Keywords: wastewater treatment plants, wastewater, pollutant loads, heavy metals

Przestano do redakcji: $26.02 .2016 r$.

Przyjęto do druku: 1.06.2016 r.

DOI: $10.7862 / \mathrm{rb} .2016 .113$ 